\title{
Health, the Outdoors and Safety
}

\author{
David J. Ball $^{1, * \mathbb{C}}$ and Laurence Ball-King ${ }^{2, *}$ \\ 1 Centre for Decision Analysis \& Risk Management (DARM), School of Science and Technology, \\ Middlesex University, London NW4 4BT, UK \\ 2 Independent Expert-Consultant, London E14 8NT, UK \\ * Correspondence: D.Ball@mdx.ac.uk (D.J.B.); laurence.ball5@googlemail.com (L.B.-K.)
}

check for

updates

Citation: Ball, D.J.; Ball-King, L. Health, the Outdoors and Safety.

Sustainability 2021, 13, 4274.

https://doi.org/10.3390/su13084274

Academic Editors: Catharine Ward Thompson and Francisca Lima

Received: 16 March 2021

Accepted: 8 April 2021

Published: 12 April 2021

Publisher's Note: MDPI stays neutral with regard to jurisdictional claims in published maps and institutional affiliations.

Copyright: (c) 2021 by the authors. Licensee MDPI, Basel, Switzerland. This article is an open access article distributed under the terms and conditions of the Creative Commons Attribution (CC BY) license (https:// creativecommons.org/licenses/by/ $4.0 /)$.

\begin{abstract}
While the public health benefits accruing from exposure to the outdoors, and especially the natural environment, have gained greater recognition, this has exposed rifts in thinking between those focusing on the pathology of injury and those pursuing a wider health agenda which recognizes the restorative potential of encounters with nature. In retrospect, the classification of injury as a public health issue in the mid-20th century triggered complex societal responses which generated unintended consequences affecting healthful activities. Responses generally aim to reduce or minimize the risk of injury and come in different forms, including formal and informal codes of practice, standards, management systems and regulation. Well-intentioned as these interventions may have been, the new emphasis on harm shifted attention away from what causes health and resulted in increasing control over activities, including those taking place outdoors. This article, which draws on long-term qualitative policy research, describes examples of these on-going tensions in the context of the public enjoyment of the outdoors. In conclusion, the situation presented is considered from a number of theoretical perspectives, and proposals are made for resolving the issues. These include improved communication between sectors and, on the technical side, the introduction of a compensatory decision process which enables policy makers to take account of both the health benefits and risks of exposure to the natural environment.
\end{abstract}

Keywords: public health; safety; wellbeing; restorative environment; risk; benefit; injury

\section{Introduction}

The natural world is hazardous, and those who venture there are inevitably exposed to some risk of harm, voluntarily or otherwise [1] (p. 12). Over the last half century, resulting injuries have come to be viewed as a public health problem rather than a consequence of fate [2-4]. This shift prompted an emphasis upon injury prevention [5-7] as opposed to the more recent interest in people's resources and capacity to create health aided by encounters with "restorative environments" [8], including nature. The exploration of this policy dichotomy through qualitative empirical research is the initial focus of this article, which then examines the findings in terms of selected theories prior to making recommendations.

The ensuing societal reactions to the injury prevention initiative, firstly in westernstyle industrial nations though gradually spreading to other nations, have manifested in the form of prohibitions, controls and national and international standards aimed at reducing or minimizing risk of injury. Meanwhile, however, the growing body of research supporting the concept of the restorative environment [9], and the greater understanding and appreciation of how exposure to nature benefits health and well-being [10-12], has given impetus to the salutogenic perspective which concerns itself with the things which promote health as opposed to those that cause disease [13].

In 2020-2021, this issue was further highlighted by the handling of the COVID-19 pandemic. During periods of lockdown in the UK, severe restrictions were placed on the public's freedoms in the interests of combatting the virus, and while some leisure activities 
were permitted for a short time each day for the purpose of "exercise", some authorities were motivated to deter the public from such therapeutic experiences as visiting parks, woodlands and coastal areas, not excluding children from playing in playgrounds and parks or building snowmen. This generated a backlash from those who suspected the consequences of some of these controls, if rigorously evaluated, would be shown to have a limited impact on the spread of COVID but a significant influence on the physical and mental health of vulnerable groups [14-16].

In this article, this collision of worldviews is described via cases taken from English courtrooms, together with studies involving the administration of public access to nature, the countryside, woodlands and playgrounds for children. The aim is to describe an ongoing and developing contest, the outcome of which will have significant implications for the pathway taken in the pursuit of public health, safety and well-being.

\section{Materials and Methods}

This article is anchored in policy research in that it seeks to provide documented knowledge about a policy issue with the objective of proposing pathways towards resolution. The evidence to be used was gathered from multiple sources over several decades. Many of these sources are of United Kingdom (UK) origin, but links and parallels with other nations and international agencies are highlighted such that a global phenomenon is addressed. The approach could be described as "accidental policy research" as defined by Majchrzak and Markus [17] (pp. 3-5), since the research has been conducted with no specific client in mind, and the researchers have retained an interest over an extended period of time and have not been restricted in their choice of method. Alternatively, Checkland and Poulter might characterize it as "action research", whereby the researcher enters the human situation, engages with it and uses that experience as the research object [18].

Unlike much policy research which utilizes secondary analysis and quantitative methodologies, this article draws upon document analysis, interviews, case studies and observation and participation in (as experts) courtroom proceedings and other contested situations $[19,20]$. Additionally, integral to the study is immersion in a number of communities with interests in the management of outdoor activities, woodlands and countryside and children's play, giving rise to what has been termed "contributory expertise", as defined by Collins and Evans [21]. These communities are identified in Section 3 of this article.

The methods deployed are qualitative and their outputs combined in an approach sometimes referred to as "bricolage" [22], which enables a fluid approach involving the use of available materials [23] supplemented by triangulation.

Expert interviews were also used, although play a minor role in this article [19]. Where used, these were semi-structured and were analysed using the methodology described by Braun and Clarke [24], which is termed thematic analysis. This requires transcripts to be generated and read open-mindedly to identify units of text relevant to the research topic, text units dealing with the same issue to be organized into groups of analytic categories, and the data to be reviewed for consistency and tabulated. In the final step illustrative quotes are assembled into a report and the collected data compared with other data sources and interpreted [19].

The collective material is discussed in terms of established and emerging theories of risk in Section 4.

\section{Findings}

The findings are described in subsections, each providing an account and illustration of a particular situation in which the narrow view of safety, namely, injury prevention, has taken a route which conflicts with the wider health perspective.

\subsection{An Illustrative and Influential Legal Narrative}

In 2003, a judgment on the acceptability of risk was made in the UK House of Lords, then the highest UK court, on a claim which had already passed through courts of the first 
instance and an appeal court [25]. At each level, the decision of the prior court had been overturned. The case involved a country park owned by a local authority which contained many features, including woodlands, a lake and sandy beaches, and which was a popular place with young people and families, attracting over 160,000 visitors per annum.

The council had, for many years, tried to deter visitors from swimming in the lake having deemed it to be "an unacceptable water activity" because of the risk of a fatal injury [25] (para. 17). This had only a limited effect on preventing persons from entering the water, and one day, years after the opening of the park, a young man executed a shallow dive into the lake and suffered a severe spinal injury. The case revolved around the legal liability of the council and in part whether it had taken sufficient steps to prevent persons entering the lake. Steps taken included signage, leaflets, planting of reeds and shrubs along the shoreline. Even dumping of ballast on the beaches to make them muddy and unattractive had been proposed.

The three presiding law lords concluded that the claimant's case should fail. In making their judgment, the following observations were made:

1. "... there was nothing ... which made it [the lake] any more dangerous than any other stretch of open water in England" [25] (para. 20);

2. "what amounts to "such care as in all the circumstances of the case is reasonable" depends upon assessing ... not only the likelihood that someone may be injured and the seriousness of the injury which may occur, but also the social value of the activity... These factors have to be balanced against each other" [25] (para. 34);

3. "It is of course understandable that organizations like the Royal Society for Prevention of Accidents should favour policies which require people to be prevented from taking risks ... But they do not have to consider the cost, not only in money but also in deprivation of liberty, which such restrictions entail." [25] (para. 47);

4. "In truth, the arguments for the claimant have involved an attack upon the liberties of the citizen which should not be countenanced. They attack the liberty of the individual to engage in dangerous, but otherwise harmless, pastimes at his own risk and the liberty of citizens as a whole fully to enjoy the variety and quality of the landscape of this country." [25] (para. 81);

The fact that the legal debate seesawed its way through the courts over several years demonstrates the existence of conflicting worldviews. While in this case it was ultimately recognized that although the environment posed obvious risks of harm, such risks had to be balanced against the benefits or social value of exposure to the environment, together with matters of personal liberty, it was far from resolved [20].

This was because the view that the risks of injury should be minimized, without reference to other considerations, remained a pervasive interpretation of UK and international legislation and standards. Although much of said regulation was directed at workplaces where risk minimization had no direct impact on public health or access to the environment, the UK was in a special situation, because its workplace legislation included a section which extended coverage to non-employees who might be affected by an undertaking. Thus, a park owner had a duty under the UK's workplace safety act [26] to not expose visitors to risks. However, another factor was that there was, in any case, a carry-over of workplace health and safety procedures to the public arena, since procedures specifically for the public arena had not been developed.

\subsection{Countryside Access and Recreation}

A parallel discourse can be traced in the context of countryside management and recreational activities. In line with the premise regarding the benefits of restorative environments, the disconnect between modern humans and nature had come to be viewed as a threat to public health [10] (p. 3), [11,27], an obvious remedy for which was to increase the public access to and use of natural places [28], which was mainly achievable in the countryside, although the greening of urban environments was another possibility. Access to the countryside, however, is dependent on landowners, and these have sometimes been 
reluctant to grant permission on the grounds of public liability should accidents occur, and a steady trickle of legal cases, criminal and civil, around risk and access had heightened concern [1] (pp. 79-103).

To facilitate access and preserve the naturalness of the countryside, the Visitor Safety Group (VSG), a consortium of interested parties in the UK, was formed in 1997 with the purpose of bringing into focus the overall advantage to society and individuals of taking a balanced approach to the risks and benefits of the outdoors, and guidance for that purpose has been published [1]. The VSG's interests encompass both safety and social utility in that their broadly stated aim is to create safe access to the countryside in ways that do not spoil the landscape and heritage or lessen the visitor's sense of exploration and adventure. Achieving such a balance, however, requires much thought and even then, may be challenged in the courtroom. The examination of court decisions [1] (pp. 79-103; 20) indeed finds that legal advisers and courts of the first instance are prone to conservatism in that the tendency is to focus on minimizing injury risk by placing restrictions and administrative burdens on providers [29].

VSG's approach to resolving the conflict is to stress that visitor safety management is about balancing benefits and risks to provide net benefits to society and individuals, and that the aim is not to seek to create a totally risk-free society or stop important recreational and learning activities. It observes that the application of modern safety precautions, which largely originate in industrial settings, may conflict with conservation, recreation or landscape objectives. For example, handrails or steps on steep mountain descents, and fencing on cliff tops, could reduce the risk of falling but could detract from the inherent attractiveness of the landscape and the desire for challenge [1], as illustrated in Figure 1.

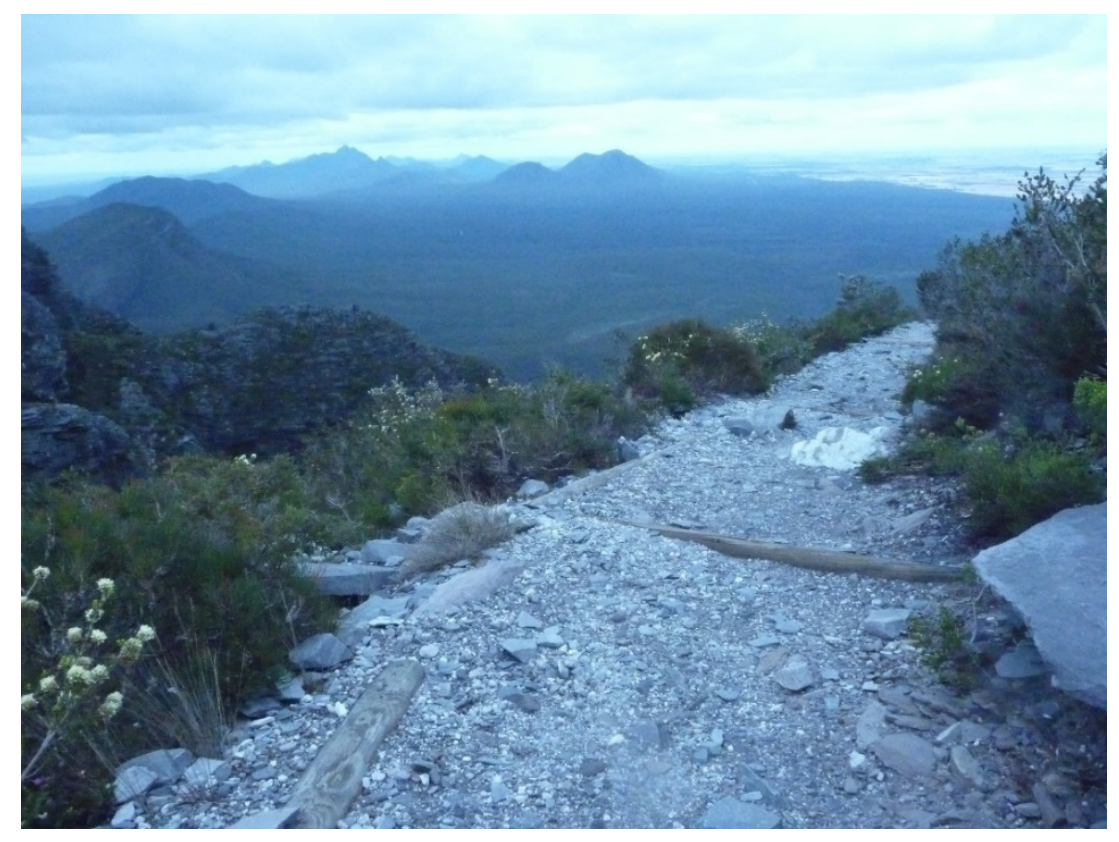

Figure 1. A popular hiking trail with an unfenced drop.

\subsection{The Management of Trees}

As with the countryside, landowners have also felt themselves pressurized because of legal liabilities resulting from the ownership of trees which may fail or shed a limb and which occasionally, though very rarely in practice [30], cause somebody harm. Whereas standard risk management protocols might see trees as hazards requiring remediation, trees, as a part of nature, are increasingly recognized for the provision of numerous services that affect the lives and well-being of people across the globe [28,31]. Advice from the central government of the UK also emphasizes the importance of "natural capital" which inter alia 
"directly benefits people through species existence, through nature-based solutions, and by enriching other benefits (like nature-based recreation)" [32].

In response to a tendency towards excessive tree removal, a consortium of UK treeowning landowners was formed in 2007 known as the National Tree Safety Group (NTSG). The group's primary purpose was to discuss the need for a nationally recognized approach to tree safety management that was proportionate to the risk posed by trees and, as they put it, "defendable rather than defensive" [33]. By 2012, the work of the NTSG had progressed rapidly such that it was able to publish guidance for landowners, large or small, on the risk management of trees. In doing this, the NTSG stressed a fundamental concept-that the evaluation of what was reasonable in relation to tree management should be "based upon a balance between benefit and risk" [33]. The NTSG describes the benefits of trees as improvements in the well-being and health of the human population, ecosystem diversity, economic activity and heritage and beauty. None of these items appears within the framework of standard risk assessment protocols, as described, for example, in European Standard 31010 [34].

A more specific contest within this sector concerns the benefits and risks posed to motorists by tree-lined roads (Figures 2 and 3). On the one hand the "Passive Safety" movement seeks to remove all hard objects, including trees, from roadside verges because of the risk to drivers who inadvertently leave the carriageway. On the other hand, tree advocates have argued that roadside trees should be retained because of their beauty and calming effect [35].

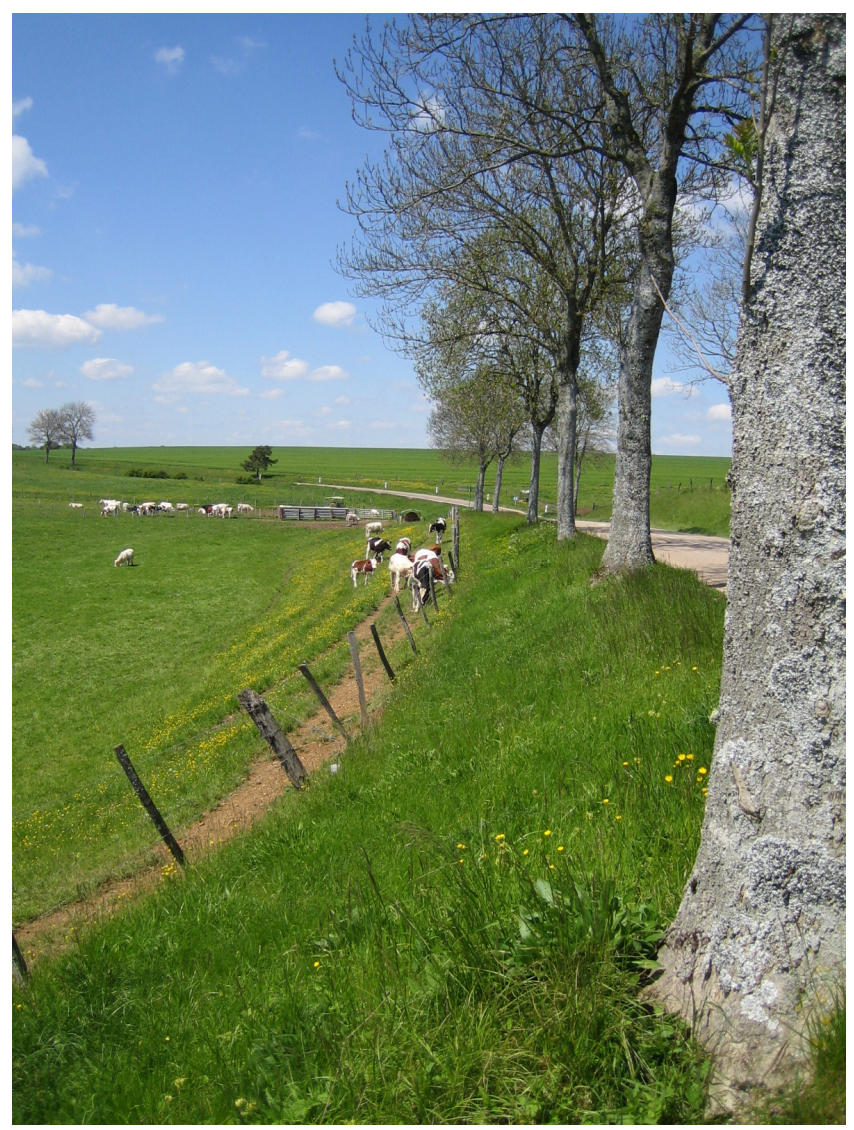

Figure 2. Should rural roadside trees be retained? (With permission of Chantal Pradines). 


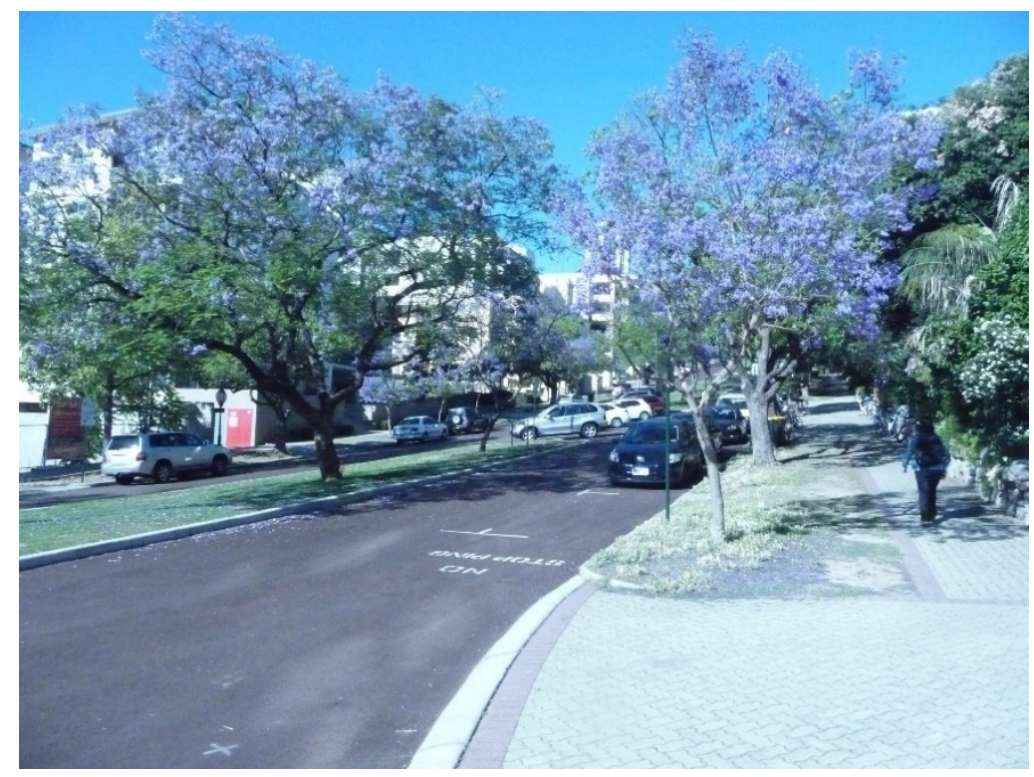

Figure 3. Urban trees offering shade and tranquillity but a potential threat to motorists.

\subsection{Children's Play}

According to Article 31 of the United Nation's Convention on the Rights of the Child, play can be distinguished from other recreational activities in that it is a developmental process whereby learning occurs as a result of the child's freely chosen and self-determined activity [36]. Thus, while activities which follow an adult-determined or standardized program of activities may be of value, they do not constitute optimal play opportunities. Most municipalities, when considering play provision, opt for adult-designed and managed playscapes comprising equipment such as swings and slides with, in many cases, undersurfaces made of synthetic materials. Such items are clearly enjoyed by children to a degree, but do not meet the wider aims of Article 31 in that self-determination is restricted. Figure 4 shows a playground which aims to bridge the gap by incorporating both natural and manufactured features.

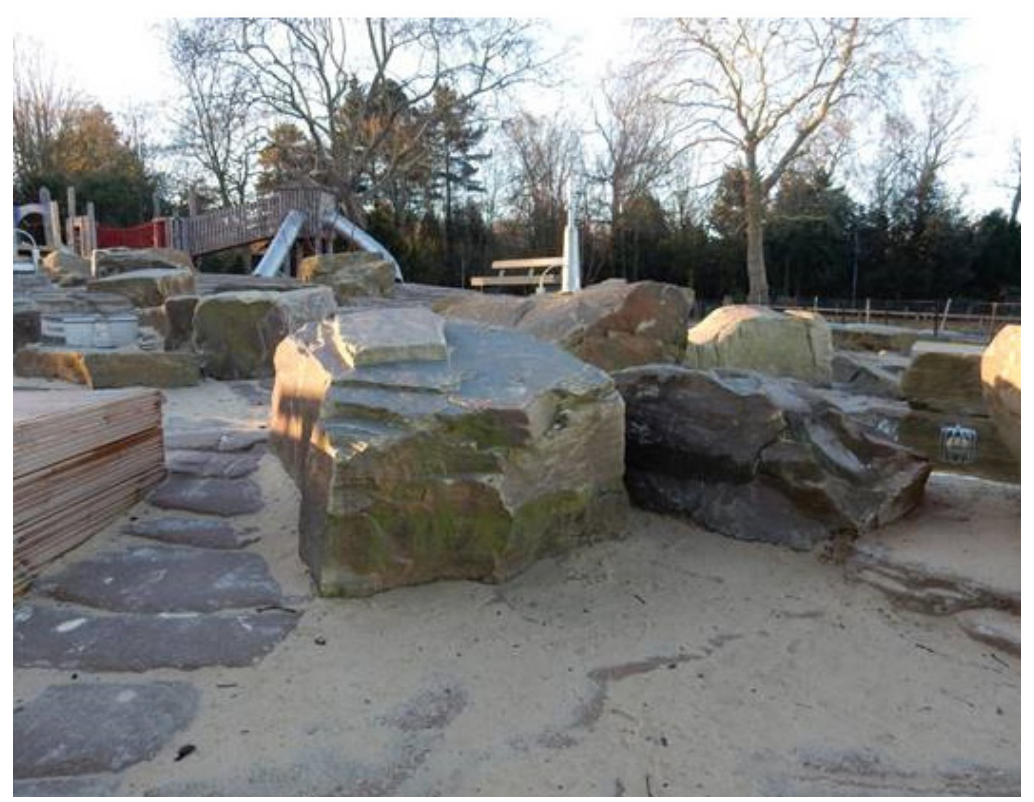

Figure 4. A playground with natural features in the foreground complementing human-made structures in the rear (with permission of Grant Lambie). 
Attempts since the 1980s to reduce the incidence of playground injuries have also had a major influence upon playground design and management (Figure 5). Detailed standards have been written prescribing what is permitted, and inspection regimes have been mandated which check for technical compliance. All of this is well-intentioned but the gathering opinion is that such play is over-prescribed and children and young people need and want a less formalized system of provision [37-39] which, inter alia, would include more natural elements.

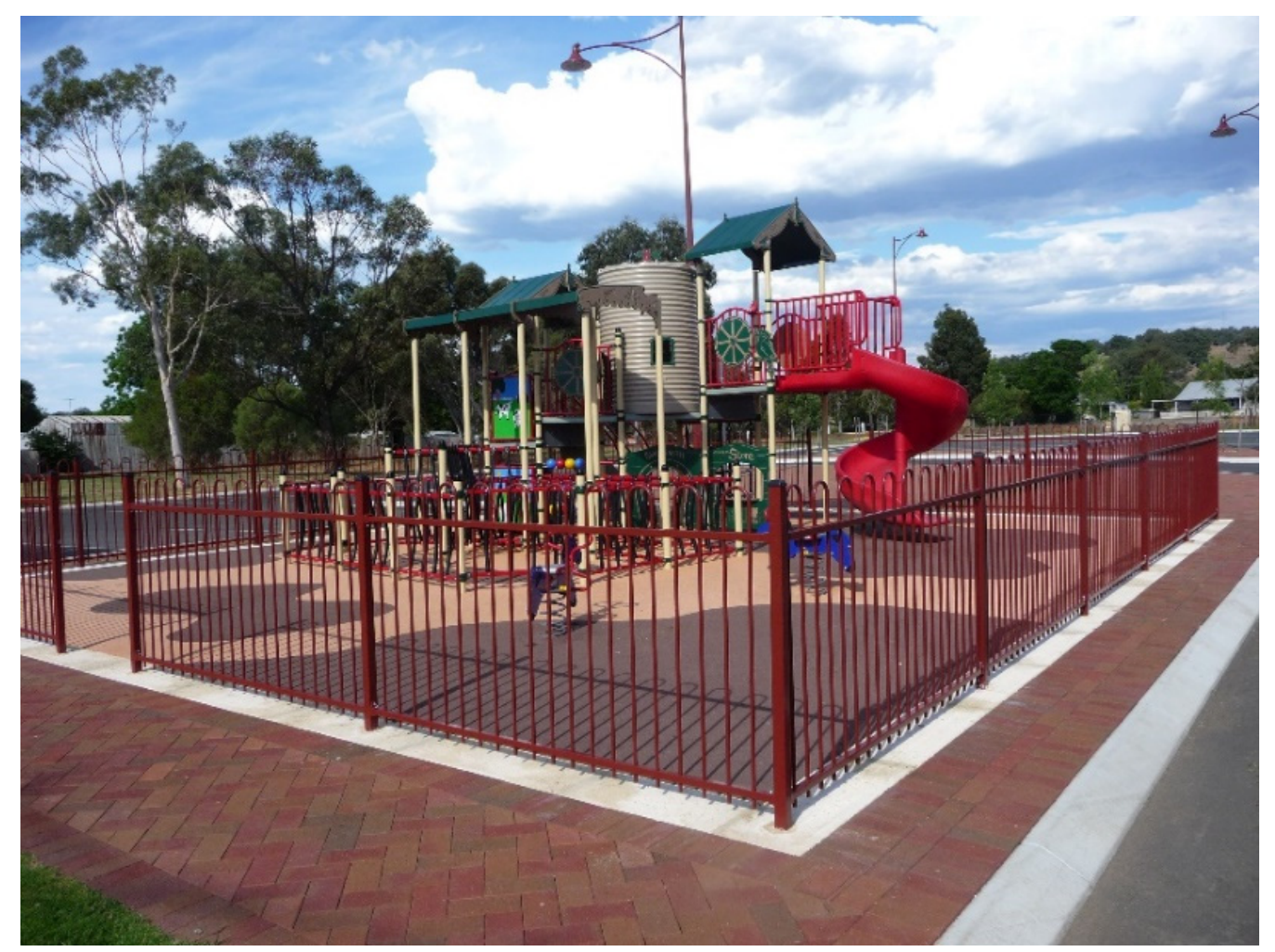

Figure 5. A playground engineered for safety.

The response in the UK was for interested parties in the four nations (England, Wales, Scotland and Northern Ireland) to form two consortia known as the Play Safety Forum (PSF) and the Children's Play Policy Forum (CPPF) which seek to represent the diverse views that exist in the play and playwork sector and strengthen commitment to play. A number of publications on the approach to play safety and play design have been published to further the objective of a balanced approach to health and safety [40,41].

\section{Discussion}

\subsection{Roots of Discord}

Exploration of the dichotomy discloses several issues. Firstly, it might be asked whether there is a dichotomy at all, as opposed to a mere spectrum of opinion. The sociologist Renn encountered a similar question in his 1992 classification of the "concepts of risk". Therein, he identified professional risk perspectives finding two extremes of positivism, in which risk was seen as objective and measurable, and constructivism which underlined the existence of multiple worldviews [42] (pp. 53-79). This is not entirely dissimilar from the currently proposed dichotomy which tends to split along an objectivist-constructivist fault line, but in Renn's analysis, he observed intervening perspectives which incorporated elements of both extremes.

However, in the present case, while there are attempts to bridge the divide (e.g., Figure 4), it is noticeable that positions are quite entrenched and that interchanges between 
the opposing positions are limited and that, to some extent at least, rifts track professional disciplines. Why might this be?

In the UK, and now internationally, the approach to safety from injury is via risk assessment and was pioneered in the industrial-cum-occupational safety sector, where systems approaches, carried over from engineering, have prevailed, and whose basic message is to "eliminate hazards and minimize occupational health and safety risks" [6] (para 0.2). Although these approaches originated in industrialized countries, they are transmitted globally via international standards on risk management, such as ISO45001 [6]. It should be acknowledged that for many applications, the systems approach has been highly successful, and consequently has numerous adherents. For example, in the USA, NASA's 1960s Apollo program enabled hundreds of agencies to work together on an intricate project and create an effective working whole [43], and this is also true of the latest Perseverance mission to Mars. However, systems engineering has been less successful when applied to social issues such as health. Checkland and Poulter describe this in the following:

"In the event, the pattern of activity found in Systems Engineering-namely, precisely define a need and then engineer a system to meet that need using various techniques-was simply not rich enough to deal with the buzzing complexity and confusion of management situations." [18]

In particular, systems engineering approaches tend to identify their purposeful activities on the basis of a single assumed worldview and without reference to the inevitability of alternative worldviews or the complexity of social contexts, and thereby lack necessary flexibility. The same preconception may also be founded in risk assessment techniques which are predominantly reductionist [44] and which inculcate a pathological perspective.

The philosopher Seedhouse offers another perspective based on Rational Field Theory (RFT), the underlying premise of which is that humans organise the world around themselves according to numerous conventions, or "rational fields".

"It is beyond doubt that evidence must be framed by human speculations, classifications, drives and instincts, social environment and history, and our personal preferences or values." [45]

While this is necessary to progress, rational fields can be snaring if they are perceived as cast in stone rather than as products of choice. Seedhouse's proposition, therefore, is that by exposing and exploring the rational fields of participants, the door is opened for constructive dialogue and understanding. Without this, opponents simply pass each other by without meaningful interaction. For Seedhouse, RFT explains the existence of the single-minded approaches to decision making that he sees in abundance across society. This reveals why different individuals favour one set of logic and evidence over another.

Risk analysts Graham and Wiener have also concluded that risk management approaches frequently suffer from bounded rationalities, risk transfer phenomena by which new risks are generated from measures designed to deal with old risks, and that many decisions are narrowly made because of the phenomenon of "absent voices" [46].

\subsection{In Search of Remedies}

It will be evident from the preceding discussion that several steps have had to be taken. Graham and Wiener argued that "omitted voices" is a pervasive syndrome in risk management and needs to be overcome. It can be seen that the formation of specialist groups, such as the VSG, NTSG CPPF and PSF, has been an essential step in combating this deficiency, all having produced authoritative guidance describing a more holistic approach, also advocated by Graham and Wiener, to decision making on the safety risks and health benefits of the outdoors.

The process of change, however, has been slow. This is partly because society has been moving into an era of explicit rules, guidance and codes of practice for everything [47], but also because understanding must infiltrate multiple stakeholders to bring about change. In 
the case of the outdoors, these include risk assessors, the courts, regulators, landowners, standards organizations and insurers, the pace of change being determined by the back marker. The writing of standards itself is a lengthy process, usually requiring international agreement. In Europe, the Comité Européen de Normalisation (CEN) has edged towards resolving the conflict between safety and health in the context of children's play when, in 2008, it stated:

"The principles of safety management are applicable both to workplaces in general as well as to play provision. However, the balance between safety and benefits is likely to be different in the two circumstances. In play provision exposure to some degree of risk may be of benefit because it satisfies a basic human need and gives children the chance to learn about risk and consequences in a controlled environment" [48]

There are also positive indications from the International Organization for Standardization (ISO). ISO45001:2018, as previously mentioned, focuses on risk minimization, but ISO31000:2018 takes a more nuanced approach to risk management and introduces a novel definition of risk as the "effect of uncertainty on objectives. Note 1 to entry: An effect is a deviation from the expected. It can be positive, negative or both, and can address, create or result in opportunities and threats" [49]. This more flexible approach is reinforced by reference to the need to ensure that different views are considered, that decisions on control should take account of wider circumstances, and that "Selecting the most appropriate risk treatment option(s) involves balancing the potential benefits derived in relation to achievement of the objectives against cost, efforts or disadvantages of implementation" [49] (para. 6.5.2). There is also an acknowledgement that risks may be retained by informed decision.

While CEN's playground standard and ISO31000:2018 move in the right direction, it is necessary to go further before support for a fully holistic approach is unequivocable. However, ISO is currently working on a new standard on "Benefit-risk assessment for sports and recreational facilities". This, if it comes to fruition, will introduce a new approach to risk assessment in which benefits of recreational activities are fully recognized and traded against risks of harm in a compensatory decision-making process [50,51], which will move much closer to a system focused on health benefits, as opposed to deficits, and the restorative potentials of the outdoors. Some agencies, such as the UK's PSF [52] and Canada's Child \& Nature Alliance [53], have taken steps in this direction.

More generally, in 2019, the Atomium European Institute for Science, Media and Democracy published a Statement of Principles for improving society's management of risks [54]. These principles provide guidance for decision makers and include, notably, that "stakeholders who agree on collective policy goals should be willing to make tradeoffs between accepting a certain level of risk in order to achieve a wider social benefit" and "Public life naturally seeks out beneficial activities. However, all life and all activities involve some risk. This means public policy decisions and personal choices must inevitably be based on trade-offs between harm and the benefit of an activity".

\subsection{Antonousky's Prescience}

The authors report that Antonovsky's contribution to the philosophy of health is not well known in the risk, safety and engineering world. However, it is evident from this article that his ideas on the determinants of health, as opposed to the conventional focus on the origins of disease and risk factors [55], provide an apt window on the dichotomy which has been described. It might be of interest to note that, even in the world of occupational safety, questions are now being asked about the focus, which has traditionally been on what went wrong in the lead up to an accident. The alternative which has been proposed is to focus on what is right in the vast majority of situations in which no accidents occur [56]. 
Author Contributions: Methodology, D.J.B. and L.B.-K.; investigation, D.J.B. and L.B.-K.; writingoriginal draft, D.J.B.; writing-review and editing, D.J.B. and L.B.-K. Both authors have read and agreed to the published version of the manuscript.

Funding: This research has no external funding.

Conflicts of Interest: The authors declare no conflict of interest.

\section{References}

1. Visitor Safety Group. Managing Visitor Safety in the Countryside_Principles and Practice, 3rd ed.; York Publishing Services: York, UK, 2019.

2. Green, J. Risk and Misfortune: A Social Construction of Accidents; UCL Press: London, UK, 2003.

3. Baker, S.P.; O’Neill, B.; Ginsburg, M.J.; Guahua, L. The Injury Fact Book, 2nd ed.; OUP: Oxford, UK, 1992.

4. World Health Organization. Preventing Injuries and Violence: A Guide for Ministries of Health; WHO: Geneva, Switzerland, 2007.

5. Risk and Regulation Advisory Council. Response with Responsibility_Policy Making for Public Risk in the 21st Century; Department for Business, Enterprise and Regulatory Reform: London, UK, 2009. Available online: https://webarchive.nationalarchives.gov. uk/20100104183913/http:/ / www.berr.gov.uk/deliverypartners/list/rrac/index.html (accessed on 12 March 2021).

6. International Organization on Standardization. Occupational Health and Safety Management Systems: ISO 45001; ISO: Geneva, Switzerland, 2018.

7. Ball, D.J.; Ball-King, L.N. Public Safety and Risk Assessment_Improving Decision Making; Earthscan: London, UK, 2011.

8. Lindström, B.; Eriksson, M. Salutogenesis. J. Epidemiol. Community Health 2005, 59, 440-442. [CrossRef] [PubMed]

9. Von Lindern, E.; Lymeus, F.; Hartig, T. The Restorative Environment: A Complementary Concept for Salutogenic Studies. In The Handbook of Salutogenesis; Mittelmark, M.B., Sagy, S., Erikkson, M., Bauer, G.F., Pelikan, J.M., Lindström, B., Espnes, G.A., Eds.; Springer: Cham, Switzerland, 2017; pp. 181-195.

10. Van den Bosch, M.; Bird, W. Nature and Public Health: The Role of Nature in Improving the Health of a Population; OUP: Oxford, UK, 2018.

11. Frumkin, H.; Bratman, G.N.; Breslow, S.J.; Cochran, B.; Kahn, P.H., Jr.; Lawler, J.J.; Levin, P.S.; Tandon, P.S.; Varanasi, U.; Wolf, K.L.; et al. Nature Contact and Human Health: A Research Agenda. Environ. Health Perspect. 2017, 125, 075001. [CrossRef] [PubMed]

12. Brussoni, M.; Gibbons, R.; Gray, C.; Ishikawa, T.; Sandseter, E.B.H.; Bienenstock, A.; Chabot, G.; Fuselli, P.; Herrington, S.; Janssen, I.; et al. What is the Relationship between Risky Outdoor Play and Health in Children? A Systematic Review. Int. J. Environ. Res. Public Health 2015, 12, 6423-6454. [CrossRef] [PubMed]

13. Antonovsky, A. Health, Stress and Coping; Jossey-Bass: San Francisco, CA, USA, 1979.

14. Cartwright-Hatton, S.; Dodd, H.; Lester, K.; Banerjee, R.; Gibson, J.; Hurding, R.; Lacey, A.; Loades, M.; Murray, J.; Pike, A.; et al. Play First: Supporting Children's Social and Emotional Wellbeing During and After Lockdown. 2020. Available online: https:/ / www.playscotland.org/resources/play-first-supporting-childrens-social-and-emotional-wellbeing-during-andafter-lockdown/ (accessed on 12 March 2021).

15. Play Safety Forum. COVID-19 and Children's Play; PSF: London, UK, 2020. Available online: https://playsafetyforum.wordpress. com/covid-19-and-childrens-play/ (accessed on 12 March 2021).

16. Moore, S.A.; Faulkner, G.; Rhodes, R.E.; Brussoni, M.; Chulak-Bozzer, T.; Ferguson, L.J.; Mitra, R.; O’Reilly, N.; Spence, J.C.; Vanderloo, L.M.; et al. Impact of the COVID-19 Virus Outbreak on Movement and Play Behaviours of Canadian Children and Youth: A National Survey. Int. J. Behav. Nutr. Phys. Act. 2020, 17, 85. [CrossRef] [PubMed]

17. Majchrzak, A.; Markus, M.L. Methods for Policy Research: Taking Socially Responsible Action, 2nd ed.; Sage: London, UK, 2014.

18. Checkland, P.; Poulter, J. Learning for Action: A Short Definitive Account of Soft Systems Methodology and Its Use for Practitioners, Teachers and Students; Wiley: Chichester, UK, 2006.

19. Ball-King, L.N. Risk Management and Proportionality: A Synoptic View of UK Practices. Ph.D. Thesis, King's College, London, UK, 2020.

20. Ball-King, L.N. Risk-based Regulation in the UK: Courtroom Battles Expose Ongoing Problems. Eur. J. Risk Regul. 2020, 1-14. [CrossRef]

21. Collins, H.; Evans, R. Rethinking Expertise; University of Chicago Press: Chicago, IL, USA, 2009.

22. Rogers, M. Contextualizing Theories and Practices of Bricolage Research. Qual. Rep. 2012, $17,7$.

23. Packer, M. The Science of Qualitative Research; CUP: Cambridge, UK, 2011.

24. Braun, V.; Clarke, V. Using Thematic Analysis in Psychology. Qual. Res. Psychol. 2006, 3, 77-101. [CrossRef]

25. House of Lords. Tomlinson $v$ Congleton Borough Council and Others; Parliament: London, UK, 2003. Available online: https: / / publications.parliament.uk/pa/ld200203/ldjudgmt/jd030731/tomlin-1.htm (accessed on 12 March 2021).

26. The National Archives. Health and Safety at Work etc Act; The National Archives: London, UK, 1974. Available online: https: //www.legislation.gov.uk/ukpga/1974/37/contents (accessed on 12 March 2021).

27. Louv, R. Last Child in the Woods: Saving Our Children from Nature-Deficit Disorder; Atlantic Books: London, UK, 2009.

28. Natural England. A Review of Nature-Based Interventions for Mental Health Care; Natural England: London, UK, 2016. Available online: http:/ / publications.naturalengland.org.uk/publication/4513819616346112 (accessed on 12 March 2021). 
29. Ball, D.J.; Maggs, D.; Barrett, M. Judges, Courts, the Legal Profession and Public Risk; Risk and Regulation Advisory Council: London, UK, 2009.

30. Ball, D.J.; Watt, J. The risk to the public of tree fall. J. Risk Res. 2013, 16, 261-269. [CrossRef]

31. Nowak, D.J. Quantifying and Valuing the role of Trees and forests on Environmental Quality and Human Health. In Nature and Public Health: The Role of Nature in Improving the Health of a Population; van den Bosch, M., Bird, W., Eds.; OUP: Oxford, UK, 2018; pp. 312-316.

32. DEFRA. Enabling a Natural Capital Approach: Guidance; DEFRA: London, UK, 2020. Available online: https://assets.publishing. service.gov.uk/government/uploads/system/uploads/attachment_data/file/869801/natural-capital-enca-guidance_2_ March.pdf (accessed on 12 March 2021).

33. National Tree Safety Group. Common Sense Risk Management of Trees; Forestry Commission: London, UK, 2011. Available online: https: / / www.forestresearch.gov.uk/documents/7075/FCMS024.pdf (accessed on 12 March 2021).

34. British Standards Institution. Risk Management_Risk Assessment Techniques; BS EN 31010:2010; BSI: London, UK, 2010.

35. Treework Environmental Practice. Tree-Lined Routes and the Linear Forest: A New Vision of Connected Landscapes; TEP Seminar 20 at Kew: London, UK, 2015. Available online: http:/ / treeworks-seminars.co.uk/resources/2015/12/27/tree-lined-routes-thelinear-forest (accessed on 12 March 2021).

36. United Nations. Convention on the Rights of the Child to Rest, Leisure, Play, Recreational Activities, Cultural Life and the Arts: General Comment No. 17; Article 31 para. 14c; UNCRC: New York, NY, USA, 2013.

37. Kennair, L.E.O.; Sandseter, E.B.H.; Ball, D.J. Risky Play and Growing Up: How to Understand the Overprotection of the Next Generation. In Pseudoscience: The Conspiracy Against Science; Kaufman, A.B., Kaufman, J.C., Eds.; The MIT Press: Cambridge, MA, USA, 2018; pp. 171-194.

38. Brussoni, M.; Olsen, L.L.; Pike, I.; Sleet, D.A. Risky Play and Children's Safety: Balancing Priorities for Optimal Child Development. Int. J. Environ. Res. Public Health 2012, 9, 3134-3148. [CrossRef] [PubMed]

39. Spiegal, B.; Gill, T.R.; Harbottle, H.; Ball, D.J. Children's Play Space and Safety Management: Rethinking the Role of Play Equipment Standards; Sage Open: Newbury Park, CA, USA, 2014; pp. 1-11. [CrossRef]

40. Ball, D.J.; Gill, T.; Spiegal, B. Managing Risk in Play Provision: Implementation Guide, 2nd ed.; National Children's Bureau: London, UK, 2013.

41. Shackell, A.; Butler, N.; Doyle, P.; Ball, D.J. Design for Play: A Guide to Creating Successful Play Spaces; National Children's Bureau: London, UK, 2008.

42. Renn, O. Concepts of Risk: A Classification. In Social Theories of Risk; Krimsky, S., Golding, D., Eds.; Praeger: Westport, CT, USA, 1992; pp. 53-79.

43. Weigal, A.L. An Overview of the Systems Engineering Knowledge Domain; MIT: Boston, MA, USA, 2010. Available online: http: / / www.yumpu.com/en/document/view/4081955/an-overview-of-the-systems-engineering-knowledge-domain-mit (accessed on 12 March 2021).

44. White, D. Application of Systems thinking to Risk Management: A Review of the Literature. Manag. Decis. 1995, 33, 35-45. [CrossRef]

45. Seedhouse, D.F. The Case for Democracy in the COVID-19 Pandemic; Sage: London, UK, 2020.

46. Graham, J.D.; Wiener, J.B. Risk versus Risk: Tradeoffs in Protecting Health and the Environment; Harvard University Press: London, UK, 1995.

47. Power, M. The Risk Management of Everything; DEMOS: London, UK, 2004.

48. British Standards Institution. Playground Equipment and Surfacing: General Safety Requirements and Test Methods; BSEN1176-1:2008; BSI: London, UK, 2008.

49. International Organization on Standardization. Risk Management Guidelines_ISO 31000; ISO: Geneva, Switzerland, 2018.

50. Yoon, K.P.; Hwang, C.L. Multiple Attribute Decision Making; Sage: London, UK, 2008.

51. Ball-King, L.N. Benefit-Risk Assessment in Sport, Recreation and Public Life. Available online: https://drive.google.com/file/d/ 1vxGYfSdCQO7QPrTUOSNIopMQOn1oJ2q-/view (accessed on 12 March 2021).

52. Play Safety Forum. Risk-Benefit Assessment Form; Play England, Play Scotland, Play Wales and PlayBoard Northern Ireland: Edinburgh, Scotland, UK, 2016. Available online: https:/ / playsafetyforum.files.wordpress.com/2015/03/cover-rba-form.jpg (accessed on 12 March 2021).

53. Gill, T.; Power, M.; Brussoni, M. Risk Benefit Assessment for Outdoor Play: A Canadian Toolkit; Child \& Nature Alliance of Canada: Ottawa, ON, Canada, 2019. Available online: https://indd.adobe.com/view/44ed054b-917b-4e02-a1e3-e6c4cbfe0360 (accessed on 12 March 2021).

54. Atomium European Institute for Science, Media and Democracy. Improving Society's Management of Risks: A Statement of Principles; Atomium: Brussels, Belgium, 2019.

55. Mittelmark, B.; Bauer, G.F. The Meanings of Salutogenesis. In The Handbook of Salutogenesis; Mittelmark, M.B., Sagy, S., Erikkson, M., Bauer, G.F., Pelikan, J.M., Lindström, B., Espnes, G.A., Eds.; Springer: Cham, Switzerland, 2017; pp. 7-13.

56. Hollnagel, E. Safety-I and Safety-II: The Past and Future of Safety Management; Ashgate: Farnham, UK, 2014. 